\title{
Fatal intracerebral haemorrhage on dual antiplatelet therapy in patient with myocardial infarction without ST elevation treated with urgent percutaneous coronary intervention- case report
}

\author{
Marijan Spasic ${ }^{1}$, Zoran Jovic ${ }^{1}$, Nemanja Djenic ${ }^{1}$, Boris Dzudovic ${ }^{1}$, Predrag Djuric ${ }^{1}$, \\ Radoslav Romanovic ${ }^{1,2}$, Slobodan Obradovic ${ }^{1,2}$ \\ ${ }^{1}$ Clinic for Cardiology and Urgent Internal Medicine, Military Medical Academy, Belgrade, Serbia, Belgrade, Serbia, \\ ${ }^{2}$ School of Medicine of the Military Medical Academy, University of Defence, Belgrade, Serbia.
}

Abstract

\begin{abstract}
According to valid guidelines for the use of dual antiplatelet therapy in patients with myocardial infarction without ST elevation (NSTEMI), the use of dual antiplatelet therapy -ASA and ticagrelor is recommended (class I level of evidence $B$ ). We report a case of a successful early percutaneous coronary intervention (early $\mathrm{PCl}$ ) in a patient with a myocardial infarction without ST elevation which received a loding dose ticagrelor after coronary angiography. We found the subtotal stenosis of the right coronary artery and stent implantation is performed.Our case showed implementation of 2015. ESC guidelines on dual antiplatelet therapy in patient with NSTEMI. The procedure was successful without periprocedural complication.but at 22 hours next day patient was intracranial hemorrhage and 48 after patient died.
\end{abstract}

Key words myocardial infarction without ST elevation, dual antiplatelet therapy; percutaneous coronary intervention; intracranial haemorrhage

\section{Introduction:}

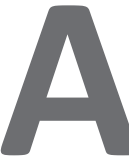
ccording to current guidelines for the use of dual antiplatelet therapy (DAPT) in patients with myocardial infarction without ST elevation (NSTEMI), the use of dual antiplatelet therapy -ASA and ticagrelor is recommended (class I level of evidence B). We report a case of a successful emergency percutaneous coronary intervention $(\mathrm{PCl})$ in a patient with a myocardial infarction without ST elevation who received a loading dose of ticagrelor after coronary angiography and decision to perform $\mathrm{PCl}^{1}$

\section{Case Report}

84-year old male patient, with chest pain was admitted to coronary unit in Military Medical Academy (MMA) several hours after the last onset of repeated chest pain. In his disease history he suffered from hypertension and diabetes mellitus type 2 . Angina started five days ago and the patient had chest discomfort on minimal effort. His physical finding on admission was unremarkable and blood pressure was 140/90 mmHg. ECG showed ST-segment depression in leads for inferior and lateral wall (Figure 1). In laboratory findings: CK and CK-MB was normal but troponin I was high 0.79 $\mu \mathrm{g} / \mathrm{L}$. Prehospital, patient received aspirin $300 \mathrm{mg}$.
NSTEMI was diagnosed and the patient was transferred to the Cath lab at 21.00 hours. Coronary angiography was showed left main and circumflex artery without significant stenosis (Figure 2) left anterior descending artery without stenosis (Figure 3 ) but subtotal stenosis in middle part right coronary artery (Figure 4).Than patient received loading doses ticagrelor $180 \mathrm{mg}$, and parenteral administration of unfractionated heparin $60 \mathrm{U}$ per kilogram of body weight. Procedure was continued was made with implantation of one stent, (bare metal stent) (Figure 5). We continued with next therapy: ticagrelor $90 \mathrm{mg}$ twice a day, aspirin $100 \mathrm{mg}$ once a day, ramipril and rosuvastatin. At 22.00 hours next day patient was complained to headache, vomiting and became comatose soon after complaints arose. Emergency cranial tomography showed massive intracranial hemorrhage (Figure 6) and 48 hours after patient died.

\section{Discussion}

In the our case DAPT received after coronary angiography and was showed one vessel coronary disease with subtotal stenosis in right coronary artery. $\mathrm{PCl}$ was successful in 84-year old male patient. However, 48 hours after $\mathrm{PCl}$ patient died from massive intracranial hemorrhage. Should we consider in people older than 

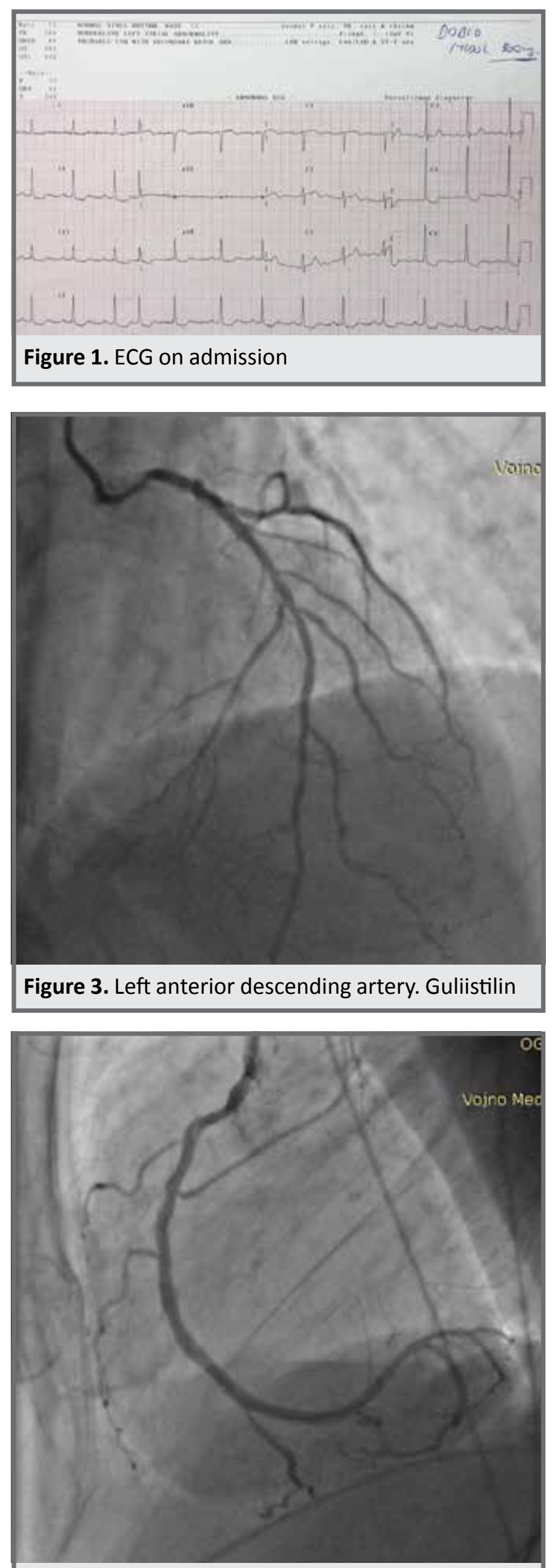

Figure 5. Right coronary artery after the $\mathrm{PCI}$
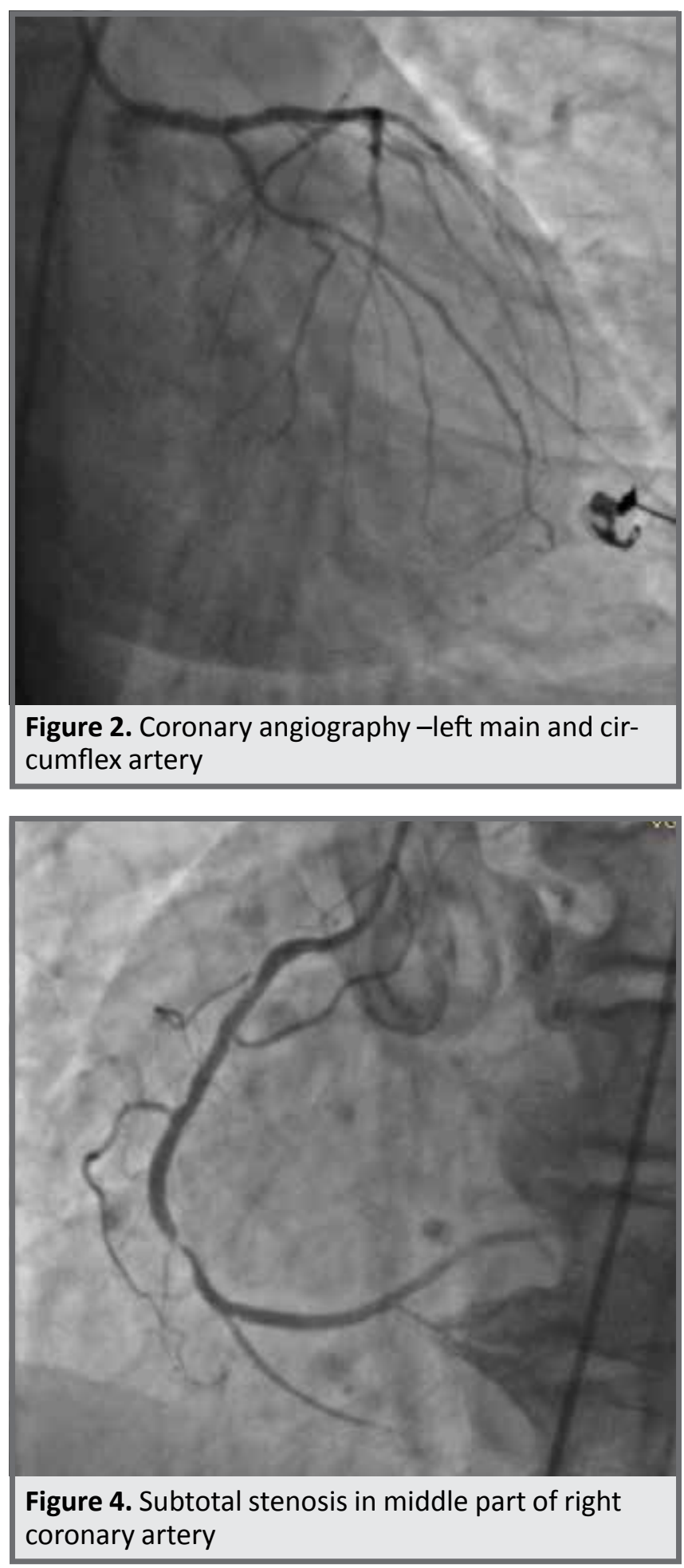

80 years of age using less potent $\mathrm{P} 2 \mathrm{Y} 12$ receptor blockers in premedication and continuation of treatment, for example, the basis of calculating the PRECISE-DAPT score on implementation of 2017 ESC guidelines on dual antiplatelet therapy in coronary artery disease. ${ }^{2}$

\section{Conclusion}

Our case showed example of implementation of 2015 ESC guidelines for the management of acute coronary syndromes in patients presenting without persistent ST-segment elevation. The procedure was successful but patient had massive, fatal intracranial hemorrhage on DAPT. 


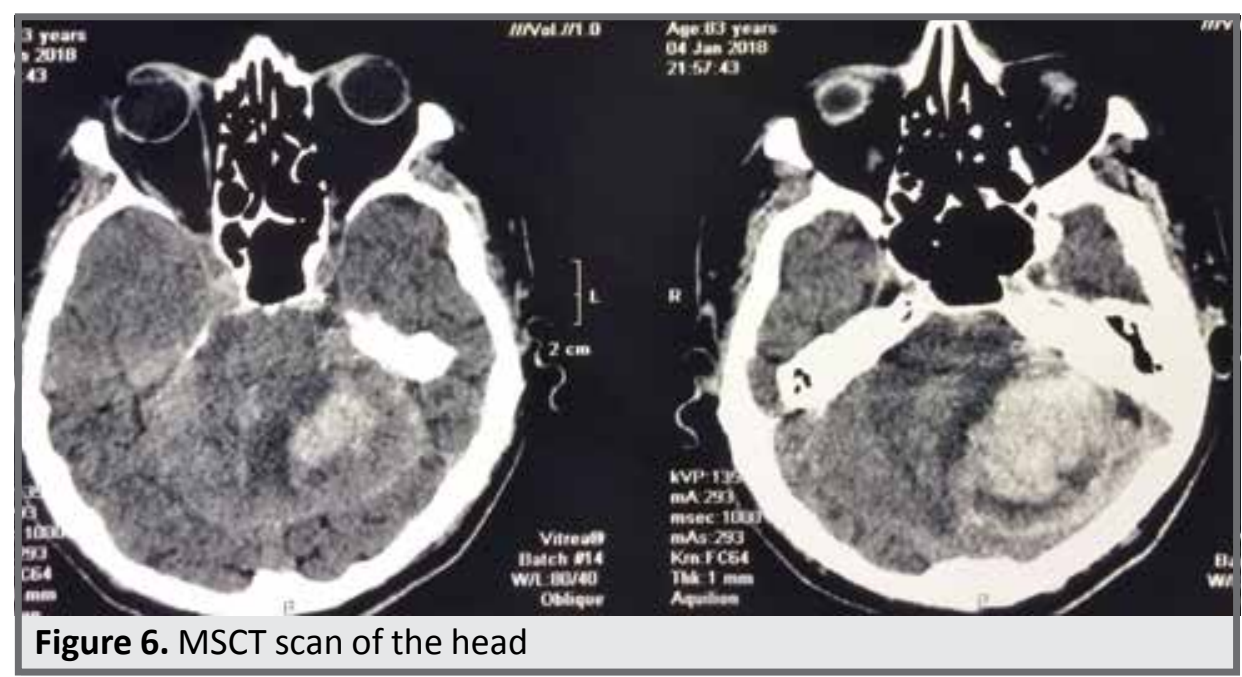

Commentary on the case according to DAPT guidelines. Current DAPT guidelines recommend more potent P2Y12 receptor antagonist before clopidogrel for the treatment of patients undergoing $\mathrm{PCl}$ for $\mathrm{ACS}$. However, non-CABG major bleeding was higher for ticagrelor and prasugrel in randomized trials which introduced these drugs. Intracranial bleeding was non-significantly higher on ticagrelor compare to clopidogrel ( 26 vs $14, p=0.06$ ) and fatal intracranial bleeding was significantly higher on ticagrelor (11 vs $1, p=0.02$ ). However, the benefit of ticagrelor regarding to reduction of major ischemic events was very pronounced and overcome this excess of intracranial bleeding. There were only $15 \%$ of patients on ticagrelor in PLATO older than 74 years and there were no signs of excess of major bleeding in this group of patients, but with a wide confidence interval for hazard ratio. We do not know how many patients was older than 80 years in PLATO and according to data we must be very careful to treat patients with ACS older than 80 years especially with the history of hypertension with more potent antiplatelet drug ticagrelor.

\section{References}

1. Roffi M, Patrono C, Collet JP, et al. 2015 ESC guidelines for the management of acute coronary syndromes in patients presenting without persistent ST-segment elevation Task Force for the management of acute coronary syndromes in patients presenting without persistent ST-segment elevation of the European Society of Cardiology (ESC). Eur Heart J 2016; 37:267-315.

2. Valgimigli M, Bueno H, Byrne RA, et al. 2017 ESC focused update on dual antiplatelet therapy in coronary artery disease developed in collaboration with EACTS. The Task Force for dual antiplatelet therapy in coronary artery disease of the European Society of Cardiology (ESC) and of the European Association for Cardio-Thoracic Surgery (EACTS). Eur Heart J 2018; 39:213-254.

\section{Sažetak}

\section{Fatalno intracerebralno krvarenje na dvojnoj antitrombocitnoj terapiji kod pacijenta sa infarktom miokarda bez ST elevacije koji je lečen urgentnom perkutanom koronarnom intervencijom}

Marijan Spasic ${ }^{1}$, Zoran Jovic ${ }^{1}$, Nemanja Djenic ${ }^{1}$, Boris Dzudovic ${ }^{1}$, Predrag Djuric ${ }^{1}$, Radoslav Romanovic ${ }^{1,2}$, Slobodan Obradovic ${ }^{1,2}$

${ }^{1}$ Klinika za kardiologiju i urgentnu internu medicinu, Vojnomedicinska akademija, Beograd, Srbija, ${ }^{2}$ Medicinski fakultet, Univerzitet odbrane, Beograd, Srbija

Po važećim smernicama za upotrebu dvojne antiagregacione terapije u pacijenata sa infarktom miokarda bez ST elevacije (NSTEMI) primena dvojne antiagregacione terapije-ASA i ticagrelora se preporučuje (klasa I nivo dokaza B). Prikazujemo slučaj uspešne urgentne perkutane koronarne intervencije ( hitna PCI) kod pacijenta sa infarktom miokarda bez ST elevacije, koji je dobio udarnu dozu ticagrelora nakon učinjene koronarografije.Verifikovana je subtotalna stenoza desne koronarne arterije i učinjena implantacija stenta. Naš slučaj je pokazao primenu 2015. ESC smernica za primenu dvojne antiagregacione terapije u pacijenata sa NSTEMI. Procedura je bila uspešna, bez periproceduralnih komplikacija ali je oko 22 sata sledećeg dana došlo do fatalnog intrakranijalnog krvarenja a 48 sati od intervencije i do letalnog ishoda.

Ključne reči: infarkt miokarda bez ST elevacije; dvojna antiagregaciona terapija, perkutana koronarna intervencija, intracerebralna hemoragija 